\title{
SaltMod estimation of root-zone salinity Varadarajan and Purandara Application of SaltMod to estimate root-zone salinity in a command area
}

\author{
Uporaba modela SaltMod za oceno slanosti \\ koreninske cone na namakalnih površinah
}

\author{
Varadarajan, N.*, Purandara, B.K. \\ National Institute of Hydrology, Visvesvarayanagar, Belgaum 590019, Karnataka, India \\ * nvarad@gmail.com
}

\begin{abstract}
Waterlogging and salinity are the common features associated with many of the irrigation commands of surface water projects. This study aims to estimate the root zone salinity of the left and right bank canal commands of Ghataprabha irrigation command, Karnataka, India. The hydro-salinity model SaltMod was applied to selected agriculture plots at Gokak, Mudhol, Biligi and Bagalkot taluks for the prediction of root-zone salinity and leaching efficiency. The model simulated the soil-profile salinity for 20 years with and without subsurface drainage. The salinity level shows a decline with an increase of leaching efficiency. The leaching efficiency of 0.2 shows the best match with the actual efficiency under adequate drainage conditions. The model shows a steady increase, reaching the levels up to 8.0 decisiemens/metre $(\mathrm{dS} / \mathrm{m}$ ) to $10.6 \mathrm{dS} / \mathrm{m}$ at the end of the 20-year period under no drainage. If suitable drainage system is not provided, the area will further get salinised, thus making the land uncultivable. We conclude from the present study that it is necessary to provide proper drainage facilities to control the salinity levels in the study area.
\end{abstract}

Key words: waterlogging, SaltMod, root-zone salinity, leaching efficiency, artificial drainage

\section{Povzetek}

Poplavljanje in slanost tal sta običajna pojava v mnogih namakalnih projektih. V študiji poročamo o ugotavljanju slanosti v koreninski coni na levem in desnem obrežju kanala namakalnega območja Ghataprabhaza v Karnataki, v Indiji. Postopek določanja slanosti z modelom SaltMod so uporabili na izbranih kmetijskih parcelah v okrajih Gokak, Mudhol, Biligi in Bagalkot za oceno slanosti koreninske cone in učinkovitosti odvodnjavanja tal. $\mathrm{V}$ raziskavi so modelirali slanost $\mathrm{v}$ talnem profilu v razdobju 20 let ob prisotnosti podpovršinskega odvodnjavanja in brez njega. Slanost upada vzporedno z naraščanjem učinkovitosti odvodnjavanja Učinkovitost 0,2 najbolje ustreza dejanski učinkovitosti v ustreznih pogojih odvodnjavanja. Model kaže stalno naraščanje do ravni 8,0 - 10,6 deci Siemens/meter na koncu 20-letnega obdobja v pogojih brez odvodnjavanja. Če ni na voljo primernega sistema odvodnjavanja, se naraščanje slanosti v območju nadaljuje, tako da postane zemlja neprimerna za obdelovanje. Iz opravljene študije sledi, da je potrebno na proučevnem območju zagotoviti ustrezno odvodnjavanje, da se zaustavi naraščanje slanosti.

Ključne besede: poplavljanje tal, SaltMod, slanost v koreninski coni, učinkovitost odvodnjevanja, umetno odvodnjavanje 


\section{Introduction}

Waterlogging is said to occur when the water table rises to within the root zone of crops. Climate, topography and geology play a dominant role in governing the occurrence, movement and storage of water. Any change in the water balance of an area causes a change in water table, leading to either waterlogging conditions or depletion of water table depending upon the nature of the change. Rise or decline in the water table is not desirable because both the phenomena degrade the sub-surface environment, thereby degrading the ground water regime [1]. Direct evaporation of ground water from the capillary fringe leads to salinisation of the soil, and in advanced stages, to the salinisation of ground water as well. Lack of aeration in the root zone, coupled with soil salinity, adversely affect crop yields in waterlogged areas. Seepage losses occurring along the routes used for the transfer of water from available resources has caused waterlogging and development of salinity in many irrigation commands. It is a fact that in some of the major projects, irrigation is in vogue for $>3$ decades, and the abacus have been stabilised with the farmers enjoying all the benefits, including access to uncontrolled use of surface water through the canals in the case of those in the upper and middle reaches of the projects [2]. With the availability of surface water throughout the year, farmers found it rarely necessary to use the ground water, with the result that ground water utilisation became almost negligible. The net result was a rise in ground water levels, gradually building up the water table, giving rise to waterlogging conditions. In addition, waterlogging also results in the accumulation of salt in the top soil or ground surface, rendering it infertile.

Purandara et al. [3] carried out a study on the waterlogging problems in the canal commands of the hard rock region of the Ghataprabha command and highlighted the problems of waterlogging and salinity in the command area. Dilip et al. [4] analysed the ground water characteristics of the Ghataprabha command under a geographic information system (GIS) environment and reported the acute problem of ground water salinity. National Institute of Hydrology (Roorkee, Uttarakhand, India) and the Remote
Sensing Directorate of the Central Water Commission (New Delhi, India) carried out a study of Ghataprabha Command Area using remote sensing and GIS [5] and delineated the waterlogged and salt-affected areas in the command. Hiremath [6] carried out a study on waterlogging and salinity, as well as the impact of major irrigation projects on agriculture land and the reclamation of affected areas in Bagalkot and Biligi taluks of the Ghataprabha Command Area. Varadarajan et al. [7] highlighted the status of salinity in the aquifers of the Ghataprabha Command Area due to a combination of various hydro-geochemical processes contributed by increase in mineralised water, rock weathering and agricultural activities.

Bahceci et al. [8] simulated the effect of different drain depths on the amount of drainage water, root zone salinity and depth of water table in the Konya-Çumra Plain, Turkey, by using SaltMod. Simulation results indicated that the leaching efficiency is 0.7 and the natural drainage is $0.120 \mathrm{~m} /$ year in the test area. Khan et al. [9] used SaltMod for suggesting remedial measures to the highly salt-affected areas. The predicted values showed very good correlation with the observed conditions, thereby indicating the applicability of SaltMod as a management tool. Hebsur [10] made detailed ground-water quality studies in the Malaprabha and Ghataprabha canal command areas using SaltMod, and the model predicted that there is a decrease in the root-zone salinity as the irrigation with good-quality water increased in combination with poor-quality waters. Shrivastava et al. [11] applied SaltMod for the Segwa minor canal command. The model predicted fairly accurate trends in the region and it was found that SaltMod is an effective tool to forecast various situations once the model is calibrated and validated for use in a given agro-climatic situation. Poornima et al. [12] estimated the root-zone salinity of salt-affected areas of some parts of Gokak and Ramdurg taluks of Belgaum District and Mudhol Taluk of Bagalkot District, Karnataka, India, using SaltMod. The model simulated the soil-profile salinity for 20 years under different conditions, viz. with and without sub-surface drainage. The salinity level shows a decline with an increase of leaching efficiency. This study aims to estimate the 


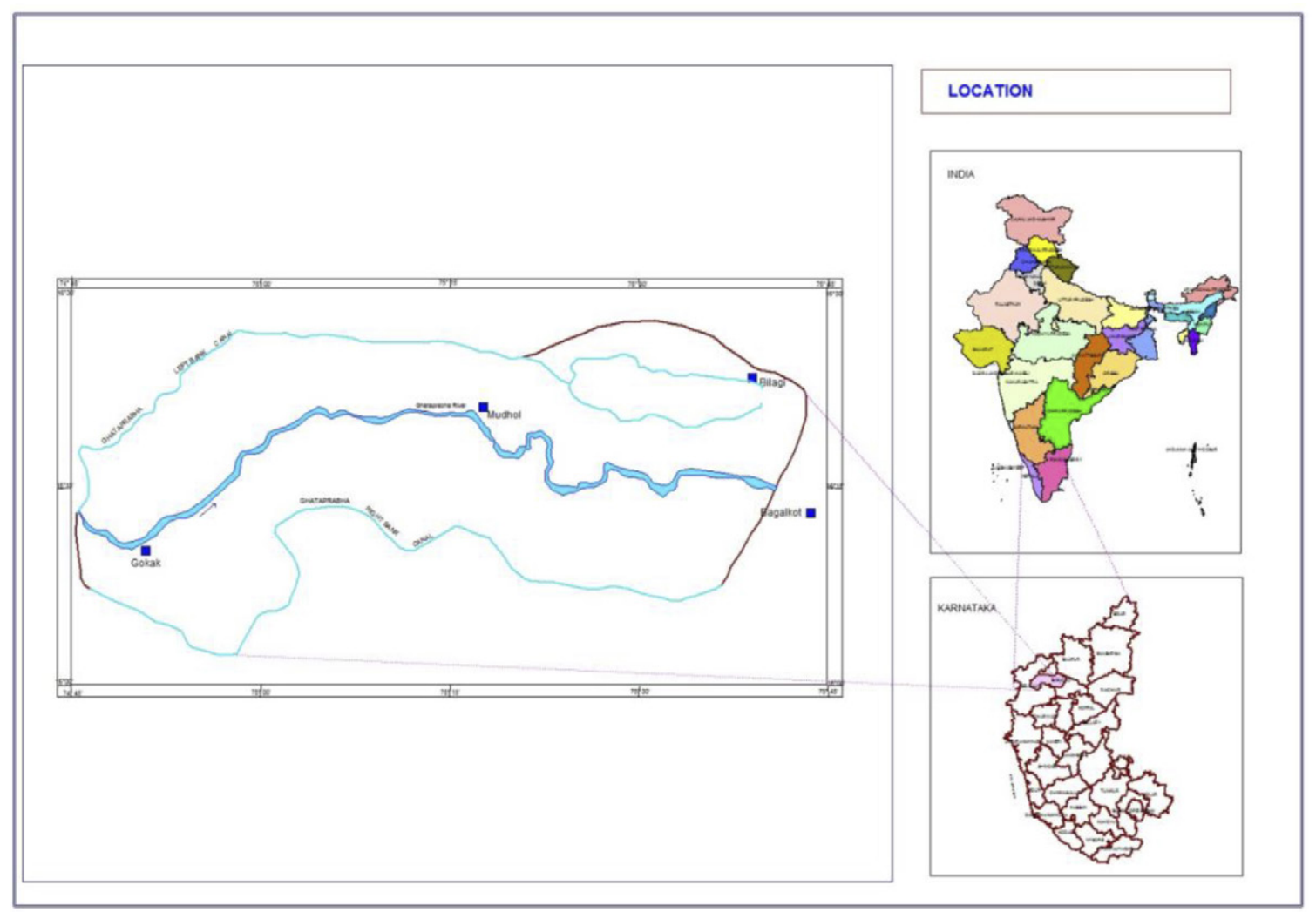

Figure 1: Index map of the study area.

root-zone salinity and leaching efficiency of the salt-affected areas of the left and right bank canal commands of Gokak, Mudhol, Biligi and Bagalkot taluks of Ghataprabha irrigation command. The hydro-salinity model 'SaltMod' was applied for this study area, which computes the salt and water balance for the root zone, transition zone and aquifer zone.

The command area of Ghataprabha reservoir is located between $16^{\circ} 0^{\prime} 8^{\prime \prime} \mathrm{N}$ and $16^{\circ} 48^{\prime} 9^{\prime \prime} \mathrm{N}$ latitudes and between $74^{\circ} 26^{\prime} 43^{\prime \prime} \mathrm{E}$ and $75^{\circ} 56^{\prime} 33^{\prime \prime} \mathrm{E}$ longitudes, covering an area of 317430 ha divided between the Belgaum and Bijapur districts of Karnataka. The index map of the study area is shown in Figure 1. The study area is bound by the Krishna River in the north, Maharashtra state to the west, the confluence of Krishna River and Malaprabha River in the east and the basin boundary between the Ghataprabha and Malaprabha rivers in the south. The existing canal command area (net command area is $161871 \mathrm{ha}$ ) is served by the Ghataprabha Left Bank Canal (GLBC) and six branch canals, with a number of major and minor distributaries.
The proposed right bank canal is expected to irrigate an area of about 155000 ha.

The topography of the area is undulating with table lands and hillocks typical of the Deccan Traps. General topographic elevation varies between 500 and $900 \mathrm{~m}$ above mean sea level with a gradual fall from the West towards the East. The catchment boundary between the rivers Krishna and Ghataprabha follows the GLBC up to Biligi. The command area essentially lies within the Krishna river basin and is drained by the Ghataprabha River. The Ghataprabha River is one of the right bank tributaries of the river Krishna in its upper reaches. The river originates from the Western Ghats in Maharashtra at an altitude of $884 \mathrm{~m}$ and flows westwards for about $60 \mathrm{~km}$ through the Ratnagiri and Kolhapur districts of Maharashtra. In Karnataka, the river flows for about $216 \mathrm{~km}$ through Belgaum District.

The command area falls in the semi-arid zone and falls under drought-hit areas. The average annual rainfall is about $700 \mathrm{~mm}$, with vide variation in time and space. The command area is 
underlain predominantly by sedimentary rocks of the Deccan Traps. Soils in the left bank canal command area are rich in clay and bases due to hydrolysis, oxidation and carbonation. However, soils in the right bank canal command area are developed due to weathering of sedimentary rocks. Soils in the area can be classified based on the geological formations. Soil depth varies from $25 \mathrm{~cm}$ to $30 \mathrm{~cm}$ in the case of shallow soils with high permeability. Deep soils with dark grey colour are found between 45 and $90 \mathrm{~cm}$ depth. Black cotton soils with an average $\mathrm{pH}$ of 8.0-8.5 generally occupy the low-lying areas. These soils exhibit high water-holding capacity but poor permeability.

The hydro-geology is complex as the Deccan Traps occupy major portions of the study area. River alluvium is found only along the course of rivers. Ground water occurs in the weathered and fractured hard rocks, as well as in the vesicular horizons in the traps. Unconfined to semi-confined conditions are observed in weathered/semi-weathered rocks. Confined conditions can be encountered when the fractures are deep seated or in vesicular horizons underlain by massive traps.

\section{Materials and Methods}

SaltMod is a computer programme for the prediction of the salinity of soil moisture, ground water and drainage water, the depth of the water table, as well as the drain discharge in irrigated agricultural lands, using different (geo) hydrologic conditions, varying water management options, including the use of ground water for irrigation, and several cropping rotation schedules. The water management options include irrigation, drainage and the use of sub-surface drainage water from pipe drains, ditches or wells for irrigation. The computer programme was originally made in FORTRAN by Oosterbaan and Isabel Pedroso de Lima at the International Livestock Research Institute (ILRI), the Netherlands [13]. A user shell in Turbopascal was developed by Ramnandanlal, and improved by Kselik of ILRI, to facilitate the management of input and output data. The schematic representation of SaltMod is shown in Figure 2.

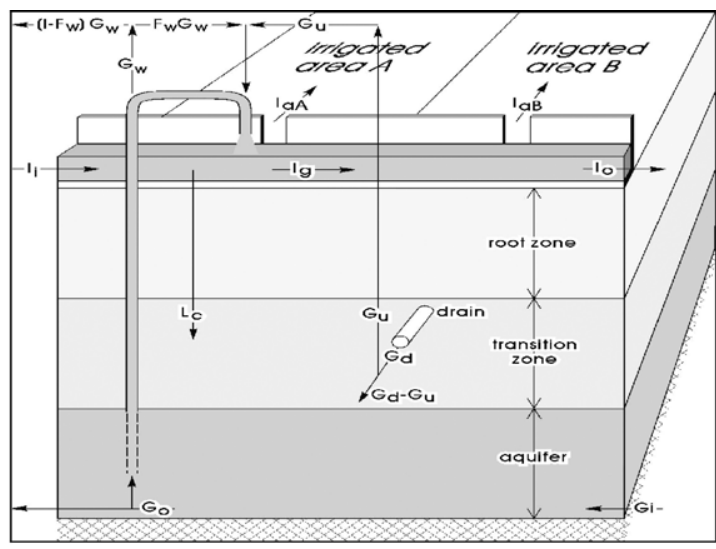

Figure 2: Schematic diagram of SaltMod.

The hydro-salinity model 'SaltMod' was applied for this study area, which computes the salt and water balance for the root zone, transition zone and aquifer zone. The computation method SaltMod is based on seasonal water and the salt balance of agricultural lands, which can be expressed by the general water balance equation as follows:

Incoming water $=$ Outgoing water \pm Change in storage (1).

\section{Results and Discussion}

The model was applied to the selected agriculture plots at Gokak, Biligi, Mudhol and Bagalkot taluks for the estimation of root-zone salinity and leaching efficiency. The model was calibrated and validated by using field-based data collected from the University of Agricultural Sciences, Dharwad, Karnataka, India. The detailed method consists of a number of iterative calculations of water and salt-balance equations to find out the final equilibrium in each zone separately. The method calculates the salt balance for each zone, based on the water balance of the individual zone and using the respective salt concentrations of the incoming and outgoing water flows. The model was run for two seasons (kharif and rabi), with full cropping rotations (the rotation index $\mathrm{Kr}=4$ ) being adopted. There are two groups of crops, viz., A and B, per season. The Group A crop consists of sugarcane, jowar, maize and bajra; and Group B consists of sugarcane, wheat, cotton, pulses and groundnut. 
Table 1: Season-wise input parameters of Gokak, Biligi, Mudhol and Bagalkot

\begin{tabular}{|c|c|c|c|c|}
\hline S. No. & Parameters & Season 1 & Season 2 & Season 3 \\
\hline 1 & Duration & 4 months & 5 months & 3 months \\
\hline 2 & Crop grown & $\begin{array}{l}\text { Sugarcane, } \\
\text { cotton, } \\
\text { jowar, maize, } \\
\text { groundnut, } \\
\text { sunflower, } \\
\text { pulses }\end{array}$ & $\begin{array}{l}\text { Sugarcane, } \\
\text { jowar, wheat, } \\
\text { cotton, pulses, } \\
\text { groundnut, } \\
\text { maize }\end{array}$ & No irrigation \\
\hline 3 & Water sources & Canal, well & Canal, well & Nil \\
\hline 4 & Fraction of area occupied (irrigated) & 1.00 & 1.00 & 0.00 \\
\hline 5 & Fallow/barren & 0.00 & 0.00 & 1.00 \\
\hline 6 & Rainfall $\left(\mathrm{m}^{3} /\right.$ season $\left./ \mathrm{m}^{2}\right)$ & 0.60 & 0.00 & 0.00 \\
\hline 7 & Water used for irrigation $\left(\mathrm{m}^{3} /\right.$ season $\left./ \mathrm{m}^{2}\right)$ & 1.00 & 1.00 & 0.00 \\
\hline 8 & $\begin{array}{l}\text { Percolation losses from the irrigation } \\
\text { canal system }\left(\mathrm{m}^{3} / \text { season } / \mathrm{m}^{2}\right)\end{array}$ & 0.01 & 0.01 & 0.00 \\
\hline 9 & $\begin{array}{l}\text { Incoming ground water flow through the } \\
\text { aquifer }\left(\mathrm{m}^{3} / \text { season } / \mathrm{m}^{2}\right)\end{array}$ & 0.50 & 0.30 & 0.00 \\
\hline 10 & $\begin{array}{l}\text { Outgoing ground water flow through the } \\
\text { aquifer }\left(\mathrm{m}^{3} / \text { season } / \mathrm{m}^{2}\right)\end{array}$ & 0.30 & 0.20 & 0.00 \\
\hline 11 & Potential evaporation $\left(\mathrm{m}^{3} /\right.$ season $\left./ \mathrm{m}^{2}\right)$ & 0.10 & 0.16 & 0.00 \\
\hline 12 & $\begin{array}{l}\text { Ground water pumped from wells in the } \\
\text { aquifer }\left(\mathrm{m}^{3} / \text { season } / \mathrm{m}^{2}\right)\end{array}$ & 0.50 & 0.50 & 0.00 \\
\hline 13 & $\begin{array}{l}\text { Fraction of water pumped by wells from } \\
\text { the aquifer used for irrigation } \\
\left(\mathrm{m}^{3} / \text { season } / \mathrm{m}^{2}\right)\end{array}$ & 0.30 & 0.30 & 0.00 \\
\hline 14 & Outgoing surface runoff $\left(\mathrm{m}^{3} /\right.$ season $\left./ \mathrm{m}^{2}\right)$ & 0.60 & 0.00 & 0.00 \\
\hline
\end{tabular}

The data required by the model are the following: seasonal average values of the areal fractions of the crops; rainfall; depth of different soil layers; values of leaching efficiency; initial salinity of the different soil layers, ground water and irrigation water; evaporation; surface runoff; reuse of drainage water and so on. The model takes the input data of each year as an average over two seasons, a wet and a dry season. The leaching efficiency of the root zone/ transition zone is defined as the salt concentration of the water percolating from the root zone/transition zone into the underground divided by the average salt concentration of the soil water in the root zone/transition zone. Leaching efficiencies of the root zone (Flr) are given a range of arbitrary values, and the corresponding salinity results of the programme are compared with the values actually measured. The efficiency producing the best match is as- sumed to be the actual efficiency. The arbitrary Flr values are taken as $0.05,0.1,0.2,0.3$ and 0.4 . The model was calibrated by using the data for the period 2001-2005 from the University of Agricultural Sciences (Dharwad), the Agriculture Department, the Irrigation Department and the Department of Mines and Geology [14]. Further, the validation was done by using the data from 2006 to 2010.

The root-zone salinity was simulated for 20 years using SaltMod under different conditions, such as with and without sub-surface drainage. For the prediction period, it was assumed that there will be no significant yearly deviations of the input parameters, such as rainfall, irrigation, evaporation, cropping pattern, etc., from the observed data given as the average input to the model for the period 2006-2010. The seasonal input and other data are shown in Tables 1 and 2 for all the locations. 
Table 2: Input parameters corresponding to soil and aquifer properties

\begin{tabular}{|c|c|c|c|c|c|}
\hline S. No & Parameters & Gokak & Biligi & Mudhol & Bagalkot \\
\hline 1 & Storage efficiency & 0.60 & 0.60 & 0.60 & 0.60 \\
\hline 2 & Depth of root zone (m) & 0.60 & 0.60 & 0.60 & 0.60 \\
\hline 3 & Depth of transition zone $(\mathrm{m})$ & 2.00 & 2.00 & 2.00 & 2.00 \\
\hline 4 & Depth of aquifer $(\mathrm{m})$ & 15.0 & 12.0 & 10.0 & 15.0 \\
\hline 5 & Total porosity of root zone $(\mathrm{m} / \mathrm{m})$ & 0.30 & 0.30 & 0.30 & 0.30 \\
\hline 6 & Total porosity of transition zone $(\mathrm{m} / \mathrm{m})$ & 0.30 & 0.30 & 0.30 & 0.30 \\
\hline 7 & Total porosity of aquifer $(\mathrm{m} / \mathrm{m})$ & 0.30 & 0.30 & 0.30 & 0.30 \\
\hline 8 & Effective porosity of root zone $(\mathrm{m} / \mathrm{m})$ & 0.05 & 0.05 & 0.05 & 0.05 \\
\hline 9 & Effective porosity of transition zone $(\mathrm{m} / \mathrm{m})$ & 0.05 & 0.05 & 0.05 & 0.05 \\
\hline 10 & Effective porosity of the aquifer $(\mathrm{m} / \mathrm{m})$ & 0.20 & 0.20 & 0.20 & 0.20 \\
\hline \multirow{4}{*}{11} & \multicolumn{5}{|c|}{ Initial salt content of the soil moisture $(\mathrm{dS} / \mathrm{m})$ at field saturation in } \\
\hline & Root zone & 2.75 & 4.25 & 4.40 & 5.25 \\
\hline & Transition zone & 2.15 & 3.65 & 4.20 & 5.00 \\
\hline & Aquifer & - & - & - & - \\
\hline 12 & $\begin{array}{l}\text { Mean salt concentration of irrigation water in the } \\
\text { pilot area }(\mathrm{dS} / \mathrm{m})\end{array}$ & 0.50 & 0.50 & 0.50 & 0.50 \\
\hline 13 & Initial depth of water table from ground surface $(\mathrm{m})$ & 1.00 & 1.00 & 1.00 & 1.00 \\
\hline 14 & Critical depth of water table for capillary rise (m) & 2.00 & 2.00 & 2.00 & 2.00 \\
\hline
\end{tabular}

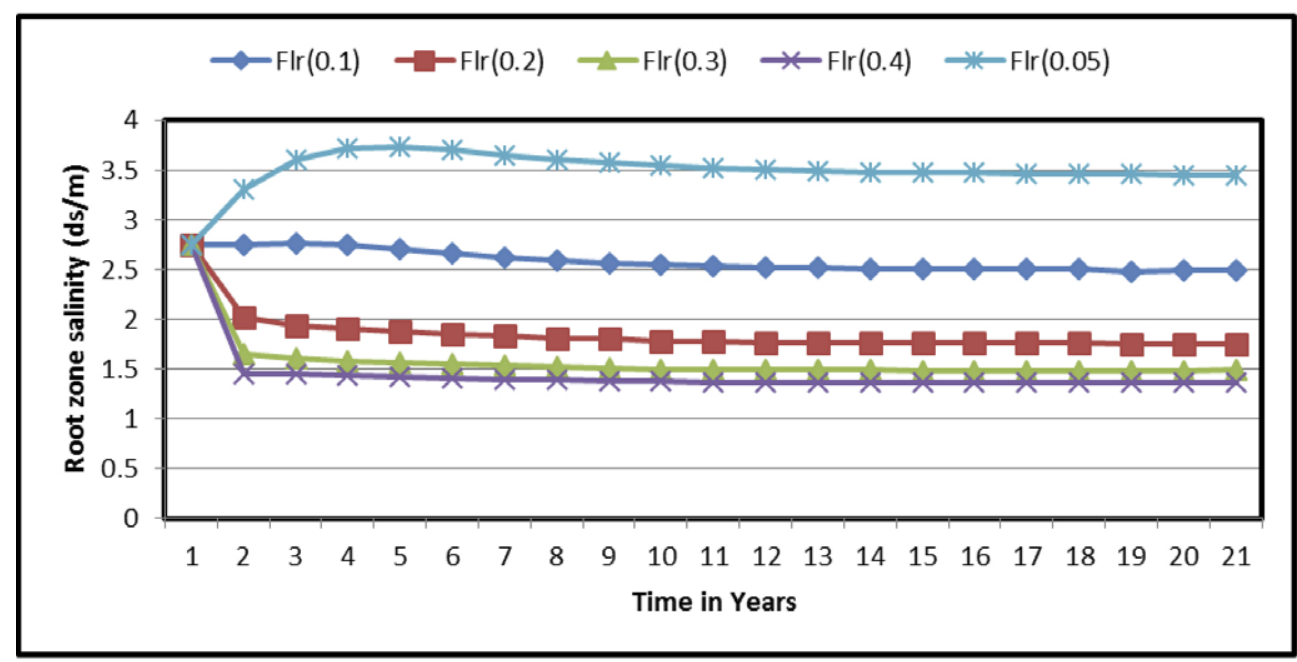

Figure 3: Predicted root-zone salinity at Gokak (with drainage).

SaltMod was applied to predict the salinity levels for the selected sites in the Ghataprabha command. This will be highly useful for taking up management decisions in the salinity-affected areas. The salinity level shows a decline with an increase of leaching efficiency. Prediction of root-zone salinity for 20 years with sub-surface drainage system is shown in Figures 3-6.
From the analysis, it is certain that the root-zone salinity declines after 3-5 years to the acceptable limits of $2.0-3.0 \mathrm{dS} / \mathrm{m}$ and became constant after 10 years for all the locations. The leaching efficiency of 0.2 shows the best match with the actual efficiency under adequate drainage conditions. However, without a sub-surface drainage system, there is a drastic increase in salinity over the years, thereby indicating the 


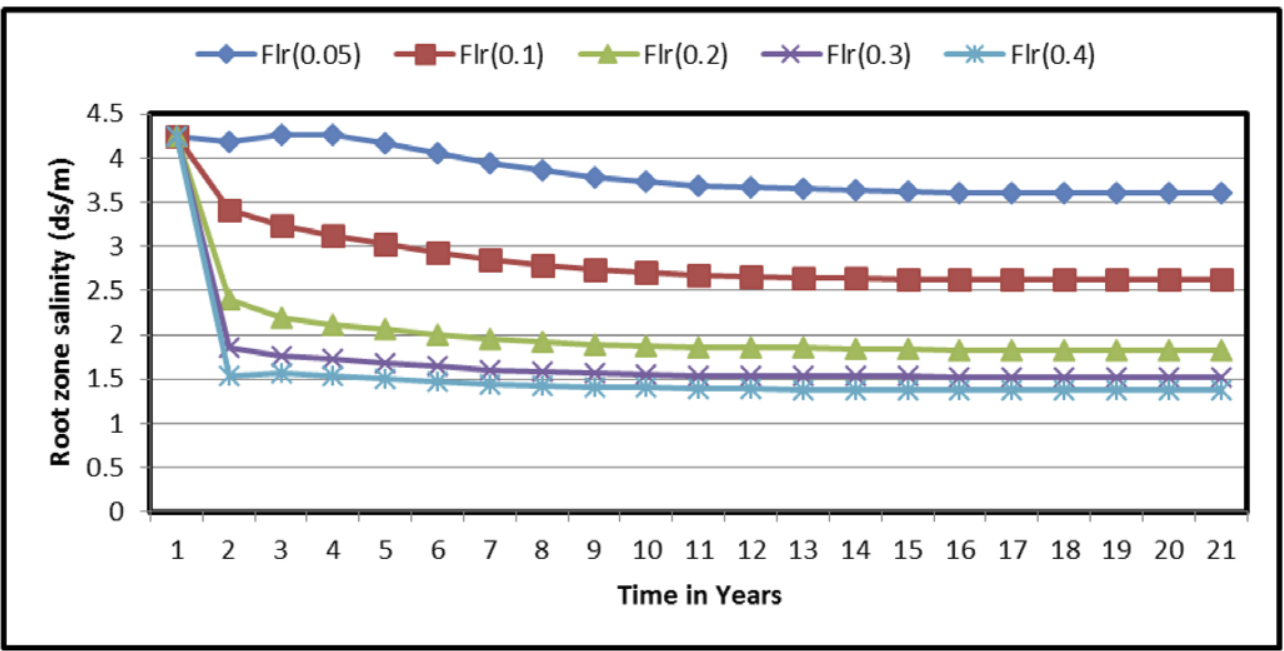

Figure 4: Predicted root-zone salinity at Biligi (with drainage).

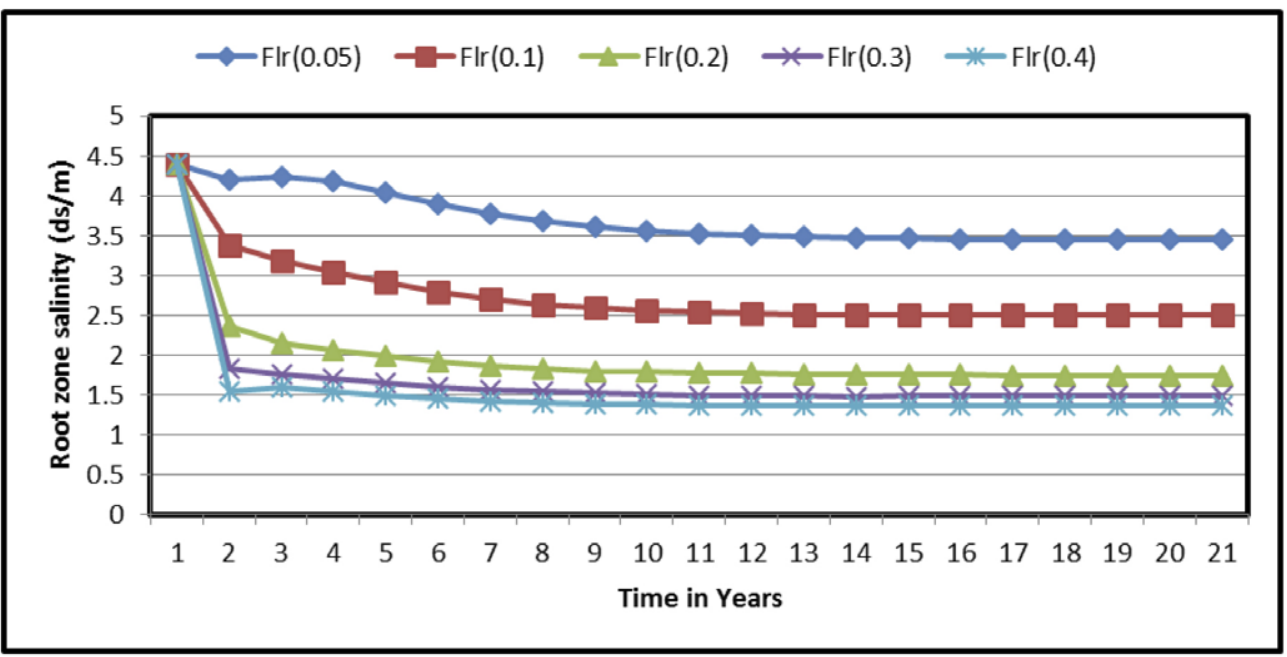

Figure 5: Predicted root-zone salinity at Mudhol (with drainage).

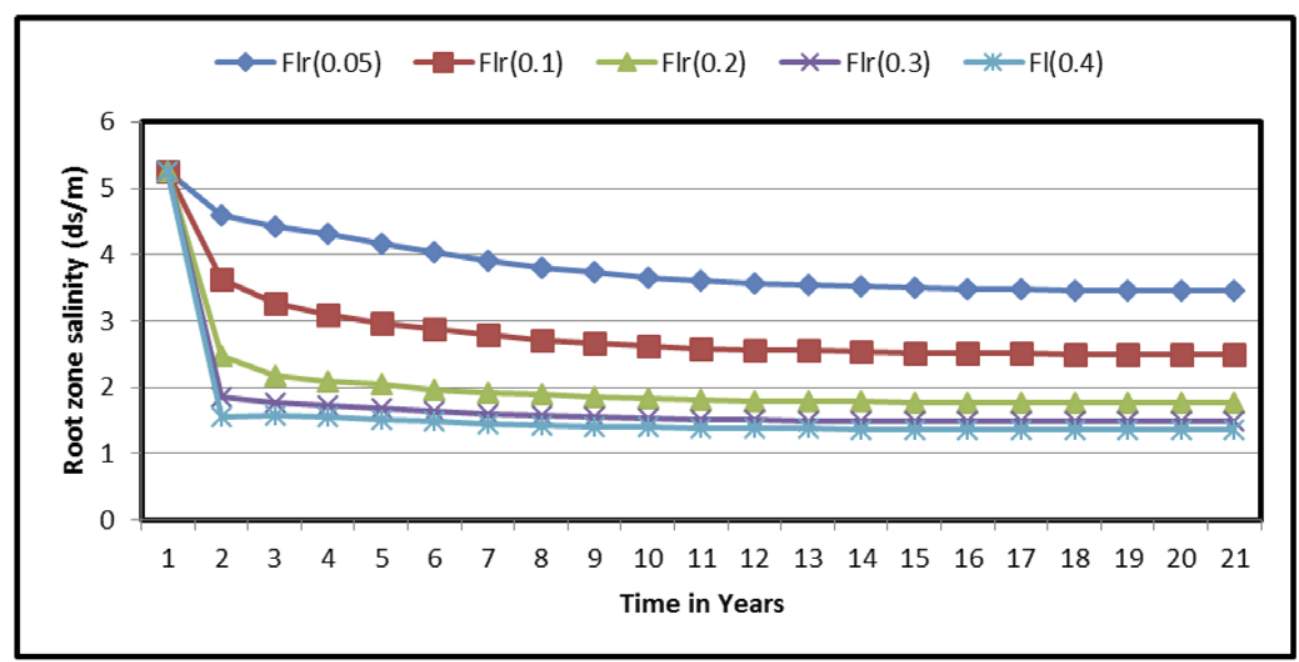

Figure 6: Predicted root-zone salinity at Bagalkot (with drainage). 


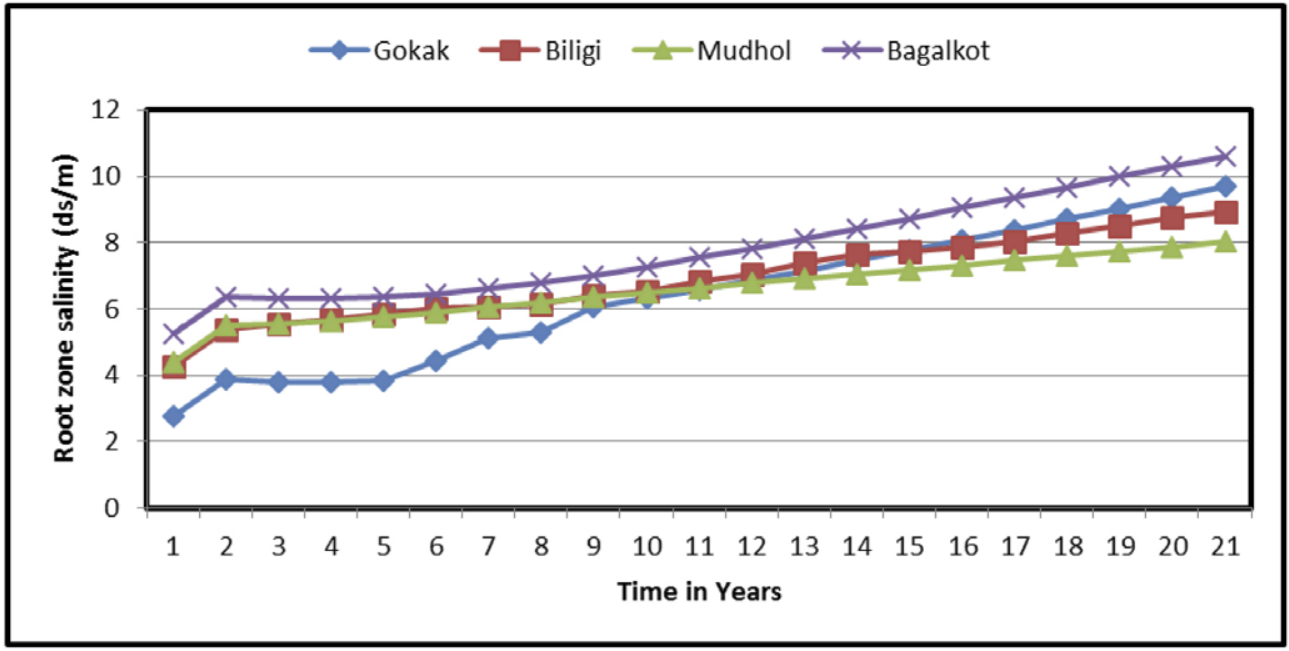

Figure 7: Predicted root-zone salinity (without drainage).

necessity of an artificial drainage system. The predicted salinity levels of the root zone without a sub-surface drainage system are shown in Figure 7 for all the locations. The model shows a steady increase, though at a slow pace over the years, reaching levels up to $8.0-10.6 \mathrm{dS} / \mathrm{m}$ at the end of the 20 -year period. If a suitable drainage system is not provided, canal command areas will further get salinised, thus making the land uncultivable. From the present study, it is evident that it is necessary to provide proper drainage facilities to control the salinity levels in the command area.

\section{Conclusions}

SaltMod, a mathematical model is applied to predict the root-zone salinity and leaching efficiency. The model simulated the soil-profile salinity for 20 years under different conditions, viz. with and without sub-surface drainage. The salinity level shows a decline with an increase of leaching efficiency. The leaching efficiency of 0.2 shows the best match with the actual efficiency under adequate drainage conditions. The root-zone salinity shows a decline after a period of 3-5 years to the acceptable limits of $2.0-3.0 \mathrm{dS} / \mathrm{m}$ and remains constant after 10 years. However, without drainage, there is a drastic increase in salinity over the years, thereby indicating the necessity of an artificial drainage system. The model shows a steady increase, though at a slow pace over the years, reaching the levels of 8.0-10.6 dS/m at the end of the 20-year period. If a suitable drainage system is not provided, canal command areas will further get salinised, thus making the land uncultivable.

\section{Acknowledgements}

The authors acknowledge the National Institute of Hydrology for carrying out this study as a part of the work programme at the Regional Centre, National Institute of Hydrology, Belgaum. The authors are thankful to the Director, National Institute of Hydrology, Roorkee, India; Dr. Sudhirkumar, Co-coordinator; and Dr. B. Venkatesh, Head, of the National Institute of Hydrology, Belgaum, for their valuable encouragement in the preparation and presentation of this technical paper.

\section{References}

[1] Sinha, B.P.C. (1986): Water-logging and drainage problems in India-an over view. In: Proceedings of the Seminar on Conjunctive Use of Surface and Ground Water Resources, Central Ground Water Board, Ministry of Water Resources, Government of India, New Delhi; pp.1-13.

[2] Central Ground Water Board, Ministry of Water Resources, Govt.of India, (1997): Report on Studies on 
Conjunctive Use of Surface and Groundwater Resources in Ghataprabha Irrigation Project, Karnataka, 180 p.

[3] Purandara, B.K., Venkatesh, B., Varadarajan, N. (1997): Water Logging problems in canal commands of Hard Rock region. In: Proceedings of Brain Storming Session on Hydrological problems of Hard Rock Region, organized by NIH, Belgaum on15th March, 1997, pp. 1-4.

[4] Dilip, G.D., Varadarajan, N., Purandara, B.K. (2002): Mapping of Groundwater Quality Parameters in GIS Environment. In: Proceedings on International Conference on Hydrology and Watershed Management held at Jawaharlal Nehru Technological University, Hyderabad during 18-20 December, pp. 568-577.

[5] National Institute of Hydrology, Central Water Commission, (2003): Report on Study of Ghataprabha Command Area using Remote Sensing and GIS, September 2003, pp.1-65.

[6] Hiremath, C.B. (2005): Water Logging and Salinity-Impact of Major Irrigation Projects on Agriculture Land and Reclamation of Affected Areas, M.Tech. Thesis, Visvesvaraya Technological University, Belgaum 2005, $120 \mathrm{p}$.

[7] Varadarajan, N., Purandara, B.K., Kumar, B. (2010): Status of Salinity in aquifers of Ghataprabha command Area, Karnataka, India. RMZ- Materials and Geo-environment, 57(3), pp. 347-362.

[8] Bahceci, I., Nazmi, D., Tari, A., Ahmet, I.G., Sonmez, B. (2006): Water and Salt balance studies using SALT-
MOD to improve subsurface drainage in the Konya-Cumra plain, Turkey. Journal of Agricultural Water Management, 85(3), pp. 261-271.

[9] Khan, N.M., Basir Ahmad, M., Latif, Y.S. (2004): Application of SALTMOD to Evaluate Preventive measures against Hydro-Salinization in Agricultural Rural Areas. Quarterly Science Vision, 9(3-4), pp. 111-117.

[10] Hebsur, N.S. (2005): Groundwater Quality Appraisal of Malaprabha and Ghataprabha Command areas and its impact on crop production and soil health, University of Agricultural Sciences, Dharwad, $230 \mathrm{p}$.

[11] Shrivastava, P.K., Patel, A.M., Oosterbaan, R.J. (2003): Saltmod Validation and Application in Segwa minor canal command area, In: Proceedings the 9th International Drainage Workshop, Utrecht, The Netherlands, September 10-13, Paper No 041.

[12] Poornima, K.B, Shiva Keshava Kumar, P., Varadarajan, N., Purandara, B.K. (2014): Estimation of Root zone salinity using SALTMOD - a case study. International Journal of Advanced Research, 2(9), pp. 858-870.

[13] [13] Oosterbaan, R.J. (2000): SALTMOD, Description of Principles, Users Manual and Examples of Application, Special Report, ILRI, Wageningen, The Netherlands, October 2000, pp. 1-80.

[14] Varadarajan, N. (2013): Ground Water Quality Assessment in the Salinity Affected Areas of Ghataprabha Command Karnataka (India), PhD. Thesis, Visvesvaraya Technological University, Belgaum, Karnataka, $284 \mathrm{p}$. 
